\title{
Spatial Variability of Soil Characteristics along a Landscape Gradient in Bellanwila-Attidiya Area
}

\author{
S. Cooray ${ }^{1}$, R.U.K. Piyadasa*2 ${ }^{2}$ and D.Wickramasinghe ${ }^{1}$ \\ ${ }^{I}$ Department of Zoology, University of Colombo, Colombo, Sri Lanka, \\ ${ }^{2}$ Department of Geography, University of Colombo, Colombo, Sri Lanka
}

Date Received: 16-10-2011～Date Accepted: 27-2-2012

\begin{abstract}
Wetlands are comprised of unique components of soil, water and biodiversity which are interconnected. Although water and biodiversity components of wetlands have been somewhat investigated, a very few research have been carried out to investigate soil properties. This study focused on spatial variability of soil chemical and physical parameters in a land use gradient around the Bellanwila-Attidiya Sanctuary, It was carried out for a period of 3 months and several random soil samples were obtained from all land use areas. Selected physical and chemical properties of soil were analyzed according to the standard methods and the GIS maps were developed using ArcView GIS 3.2.

The results indicated that selected chemical and physical parameters of soil varied across the land use gradient, except for temperature. According to the GIS maps there are apparent variations in distribution of soil properties. On the surface, the highest level of each parameter was found as follows: - $\mathrm{NO}_{3}{ }^{-}$- industrial area, $\mathrm{PO}_{4}{ }^{3-}$ - functioning paddy fields, $\mathrm{SO}_{4}{ }^{2-}$ - residential area, $\mathrm{Cl}^{-}$- residential area, $\mathrm{Fe}^{3+}$ - functioning paddy fields, moisture content - wetland, $\mathrm{pH}$, acidic - industrial area, salinityresidential area, electrical conductivity - residential area. At a $1 \mathrm{~m}$ depth, the pattern was different: $\mathrm{NO}_{3}{ }^{-}$ - abandoned paddy fields, $\mathrm{PO}_{4}{ }^{3-}$ - functioning paddy fields, $\mathrm{SO}_{4}{ }^{2-}$ - wetland, $\mathrm{Cl}^{-}$- wetland, $\mathrm{Fe}^{3+}$ residential area, moisture content - wetland, $p H$ - industrial area, salinity - wetland, electrical conductivity - wetland. The findings clearly exhibit the increases in anthropogenic pressure have resulted in wide-scale alternation of soil properties, at least in the surface soil, across a land use gradient. Managing land use in the watershed of the wetland thus needs adequate attention to conserve this natural ecosystem.
\end{abstract}

Key words: soil, physical and chemical parameters, wetland, GIS

\section{Introduction}

Wetlands are comprised of characteristic components of soil, water and biodiversity which interact with each other to give rise to a unique environment (Holland et al., 2003). Wetlands are amongst the world's most valuable and vulnerable environments on which a variety of plants, animals and human communities depend (Kotagama and Bambaradeniya, 2006; Finlayson et al., 2007). Given its favorable topography and climate, Sri Lanka supports a wide array of wetlands which possess various ecological functions and values.

*Correspondence: ranjana@geo.cmb.ac.lk

Tel-++ 94112500458 , Fax- ++ 94112500458

ISSN 2235-9370 Print / ISSN 2235-9362 Online C2012 University of Sri Jayewardenepura 
Wetland ecosystems are dynamic and heterogenic, which can exhibit substantial spatial and temporal variability in soil properties (Grunwaldet al., 2006) which can be influenced by the land use pattern of the area (Bruland and Richardson, 2005). This variability can have important consequences on wetland biota and biogeochemistry. Soil of wetland often saturated, flooded, or inundated long enough during the growing season to develop anaerobic conditions in the upper part. The composition of soil of a wetland contributes to characteristics of the habitat. There are primarily two types of wetland soil, mineral soil and organic soil. Almost all wetlands have organic soil, but if the organic matter content of the soil is less than 20-35 percent organic matter, it is considered a mineral soil (Street, et al. 2005). Table 1 depicts different properties of organic and mineral soils in wetlands.

Table 1: Comparing mineral and organic soils in wetlands (Street, et al. 2005)

\begin{tabular}{lll}
\hline Description & Mineral Soil & Organic soil \\
\hline Organic Content, percent & Less than 20-35 & Greater than 20-35 \\
Organic Carbon, percent & Less than 12 to 20 & Greater than 12- 20 \\
pH & Usually circumneutral & Acidic \\
Bulk Density & High & Low \\
Porosity & Low $(45-55 \%)$ & High $(80 \%)$ \\
Hydraulic Conductivity & High (except for clays) & Low to high \\
Water holding capacity & Low & High \\
Nutrient availability & Generally high & Often low \\
Cation exchange capacity & Low, dominated by major cations & High, dominated by hydrogen ion \\
Typical Wetland & Riparian forest, some marshes & Northern Peatland \\
\hline
\end{tabular}

Wetland soils need to be evaluated based on the available nutrient levels, proportions of sand, silt, clay, gravel content, organic material, permeability, drainage potential, erodibility, soil chemistry (Heidi, 1997). The incidence of these exceptional properties within the landscape can be used as indicators of wetland conditions to determine whether they are altered or not (Cwikiel, 2003).

Soils can be referred to as media for processes, functions and primary production of an ecosystem (Cosmas, 2009). It contains heterogeneity of nutrients that are made available to plants when the conditions are sufficient enough to make them solubilise (Kidane and Pieterse, 2006); and assimilable by plants.Preservation of wetland habitat is of the utmost importance because the areas provide beneficial uses for humans, such as reducing soil erosion, recharging groundwater, and aesthetic beauty (United States Environmental Protection Agency, 2001). Wetlands are also involved in many biological and chemical processes which transform nutrients, sequester heavy metals and organic compounds (United States Environmental Protection Agency, 2001). Pollution from agricultural and other anthropogenic sources have been identified as the major cause of degradation of water bodies (United States Environmental Protection Agency, 1996).

Although adequate attention has been paid to water and biodiversity components of wetlands, there are only a few studies that describe wetland soils in Sri Lanka (Atapattu et al., 2007). This study investigates the spatial variability of soil chemical and physical parameters in a land use gradient around the Bellanwila-Attidiya Sanctuary, situated in Colombo suburbs.

\section{Materials and Methods}

This study was conducted in Bellanwila-Attidiya wetland which is located in the south eastern bounds of Colombo between $6052^{\prime} 0 \mathrm{~N}$ and 790 52' $0 \mathrm{E}$ to $6048^{\prime} 0 \mathrm{~N}$ and $79056^{\prime} 0 \mathrm{E} ; 759157 \mathrm{~N}$ and $374779 \mathrm{E}$ to $751770 \mathrm{~N}$ and $382129 \mathrm{E}$; in the Colombo District of the Western Province. The marshes are about 372 hectares (approximately about 1,000 acres) in area. This is largely a freshwater marsh 
ecosystem, bounded by a swiftly developing urban landscape (International Water Management Institute, 2006).

This study was carried out for a period of 3 months from February 2011 to April 2011 and the site was visited once in two weeks and soil samples were taken by using a soil borer in randomly selected places. Sampling was carried out in triplicate on each day. The study site represented by the wetland itself (WL) which is the main marsh and surrounding different land use areas i.e. functioning paddy fields (FPF), abandoned paddy fields (APF), residential area (RA) and industrial area (IA) (Figure 1). The soil chemical properties viz. $\mathrm{NO}_{3}{ }^{-}, \mathrm{PO}_{4}{ }^{3-}, \mathrm{SO}_{4}{ }^{2-}, \mathrm{Cl}^{-}, \mathrm{Fe}^{3+}, \mathrm{pH}$, salinity and electrical conductivity and physical properties viz. moisture content, temperature, soil type and soil color were measured at two levels: at the surface level (top) and at $1 \mathrm{~m}$ depth (bottom) from the surface. Samples were analyzed in the Soil Laboratory of the University of Colombo. Table 2 depicts the standard methods adopted to analyze soil samples.

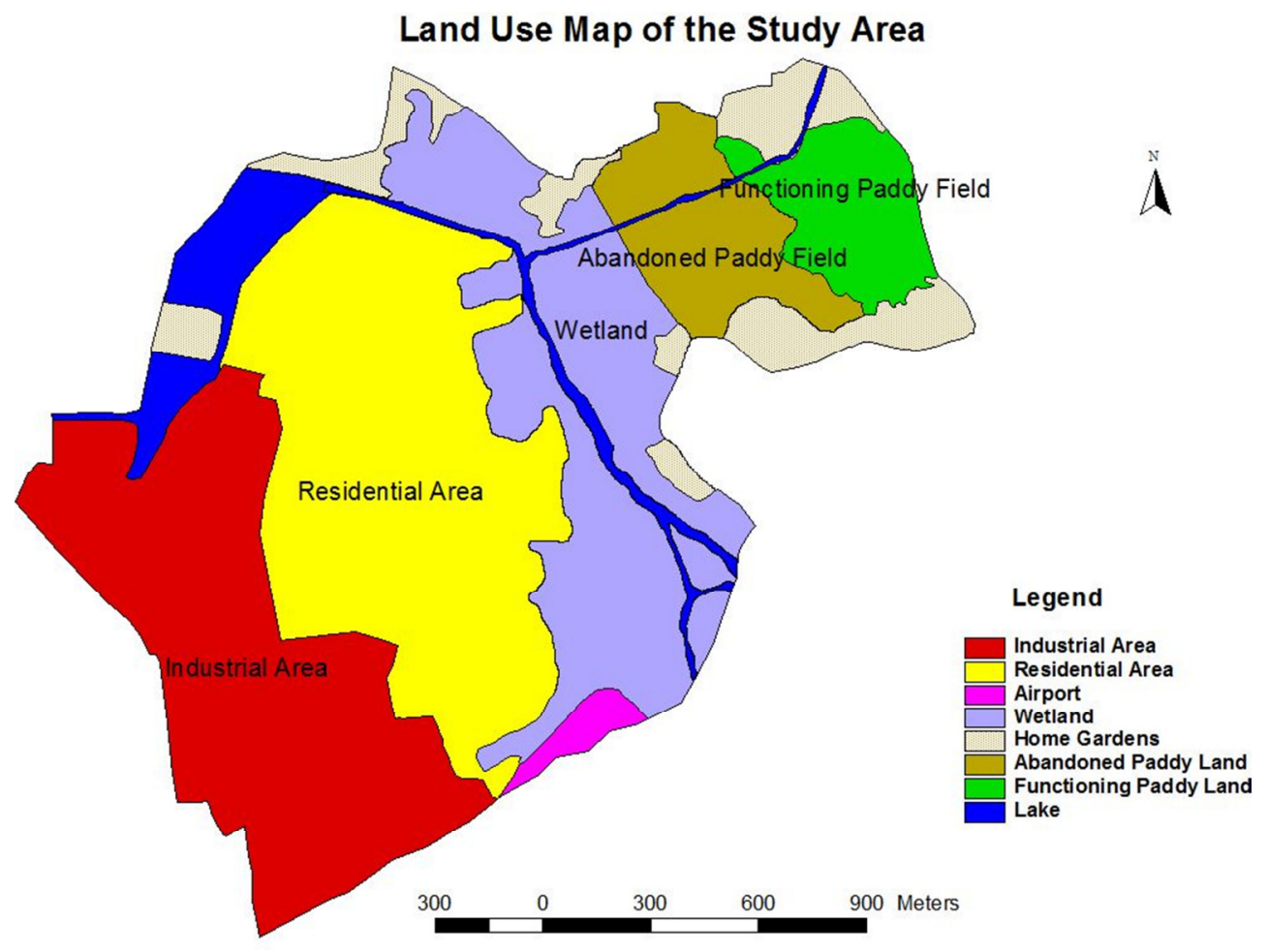

Figure 1: Land use map of the Bellanwila-Attidiya area

By pooling data for a particular land use area, means and standard deviations were determined for each parameter investigated. One-way analysis of variance (ANOVA) was used to compare soil properties among sites. Least Significant Difference (LSD) Multiple Comparison Analysis was carried out to identify which combinations of land use areas gave the significant difference from each other ( $\mathrm{p} \leq$ 0.05) in aforesaid parameters. All statistical analysis was performed using SPSS version 16.0 for windows.

The GIS maps were developed to indicate variation in physical and chemical parameters in relation to different land use areas. Further GIS was used to represent the study area and its land use patterns using ArcView GIS 3.2. Data were positioned in the soil triangle to define the soil type of each area. Soil colour was determined using Munsell soil colour chart (Black, 1965). 
Table 2: Methods used in analysing physical and chemical parameters of soil

\begin{tabular}{ll}
\hline Soil Parameter & Method \\
\hline Temperature & Soil thermometer at the sampling site. (Black, 1965) \\
Soil moisture cont. & Drying method (Black,1965) \\
pH & pH meter dipped in a soil-water suspension 1:2 (Black, 1965) \\
Salinity & Salinity-Conductivity meter (Black, 1965) \\
Electrical conductivity & Salinity-Conductivity meter (Black,1965) \\
Soil type & Drying method (Black,1965) \\
Soil Colour & Munsell soil colour chart (Black,1965) \\
Nitrate, Phosphate and Sulphate & UV visible Spectrophotometry (Clesceriet al. 1999) \\
Chloride & Titration, Silver nitrate method (Clesceriet al. 1999) \\
Iron (III) & Atomic absorption spectrophotometry (AAS) (Clesceri et al. \\
& 1999) \\
\hline
\end{tabular}

\section{Results}

According to soil analysis results, on average, higher percentage of clay was found in bottom soil layers of some areas. A similar pattern was observed when the soil triangle was developed using the data obtained. It showed that the soil type in bottom soil layers of all the land use areas were identified as clay soil, while the top soils of residential area and industrial area were also recognized as clay soil. Both functioning paddy fields and abandoned paddy field have silt loam in its top soil layers. Silt clay loam was the soil type in wetland top layer (Table 3).

Table 3: Soil colour and soil type in different land use areas

\begin{tabular}{llll}
\hline Land Use & Layer & Soil Type & Colour \\
\hline Functioning Paddy Field & Surface & Silt loam & Pale brown \\
& $1 \mathrm{~m}$ & Clay & Gray \\
Abandoned Paddy Field & Surface & Silt loam & Very dark greyish brown \\
& $1 \mathrm{~m}$ & Clay & Gray \\
Wetland & Surface & Silt clay loam & Brownish black \\
& $1 \mathrm{~m}$ & Clay & Gray \\
Residential Area & Surface & Clay & Bright brown \\
& $1 \mathrm{~m}$ & Clay & Gray \\
Industrial Area & Surface & Clay & Bright brown \\
& $1 \mathrm{~m}$ & Clay & Bright brown \\
\hline
\end{tabular}

The results further indicated that all chemical and physical parameters of soil varied across the land use gradient, except for temperature. The results are summarized in Table 4. The highest values obtained for all parameters differed in different land use settings (Table 4). The pattern observed for the highest levels for each parameter on the surface was found as follows: - On the surface: $\mathrm{NO}_{3}{ }^{-}$ industrial area, $\mathrm{PO}_{4}{ }^{3-}$ - functioning paddy fields, $\mathrm{SO}_{4}{ }^{2-}$ - residential area, $\mathrm{Cl}^{-}$- residential area, $\mathrm{Fe}^{3+}$ functioning paddy fields, moisture content - wetland, $\mathrm{pH}$ - industrial area, salinity- residential area, electrical conductivity - residential area. At a $1 \mathrm{~m}$ depth the pattern was different: $\mathrm{NO}_{3}{ }^{-}-$abandoned paddy fields, $\mathrm{PO}_{4}{ }^{3-}-$ functioning paddy fields, $\mathrm{SO}_{4}{ }^{2-}-$ wetland, $\mathrm{Cl}^{-}$- wetland, $\mathrm{Fe}^{3+}$ - residential area, moisture content - wetland, $\mathrm{pH}$ - industrial area, salinity - wetland, electrical conductivity - wetland. 
Table 4: Mean \pm SD of soil parameters along a land use gradient

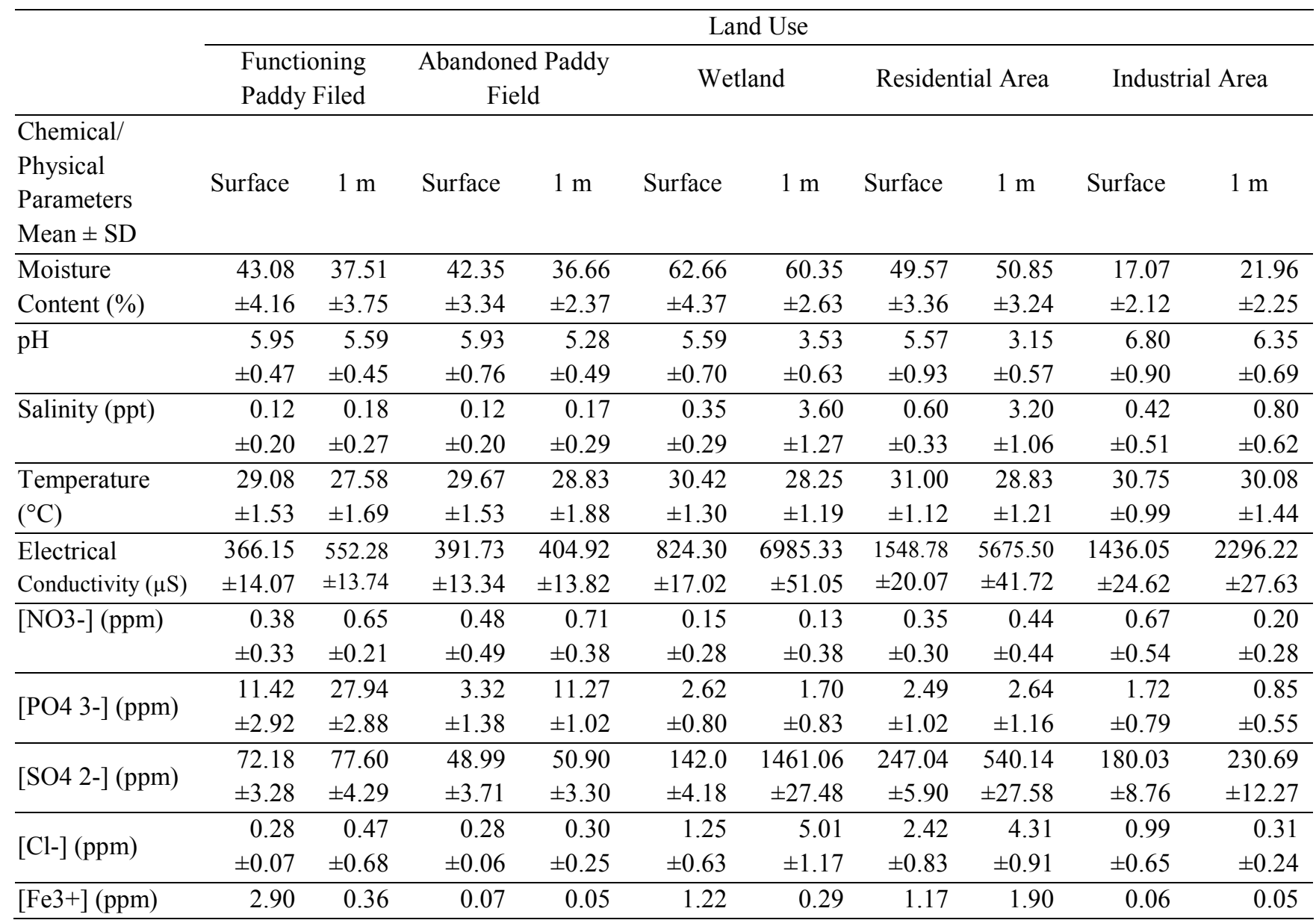

Maps generated using GIS data indicating the distribution of nitrate and phosphate levels in different land use areas in both top and bottom soil layers are depicted in Figures 2, 3, 4, and 5 respectively.

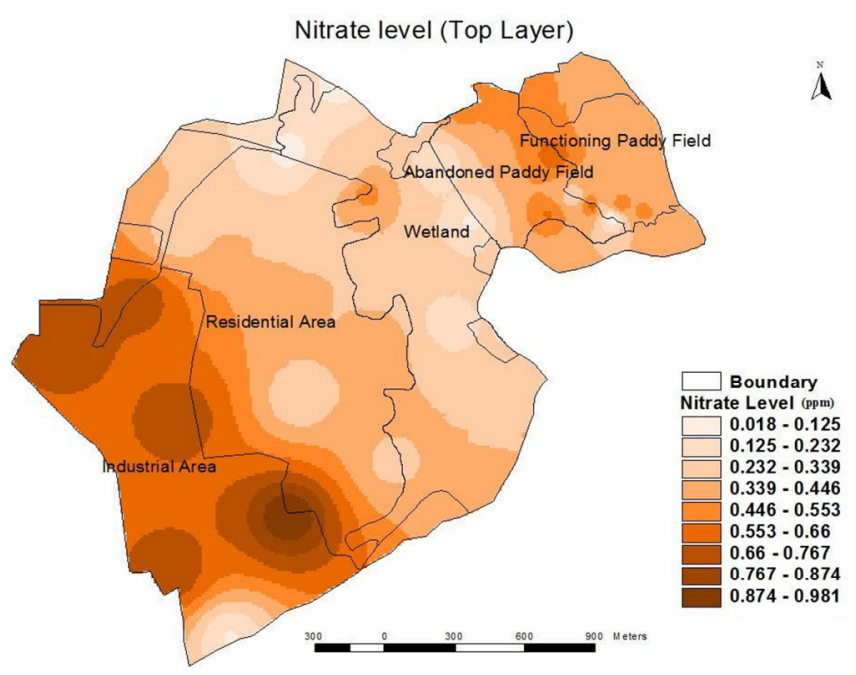

Figure 2: Distribution of water soluble nitrates in top soil layer in the study area

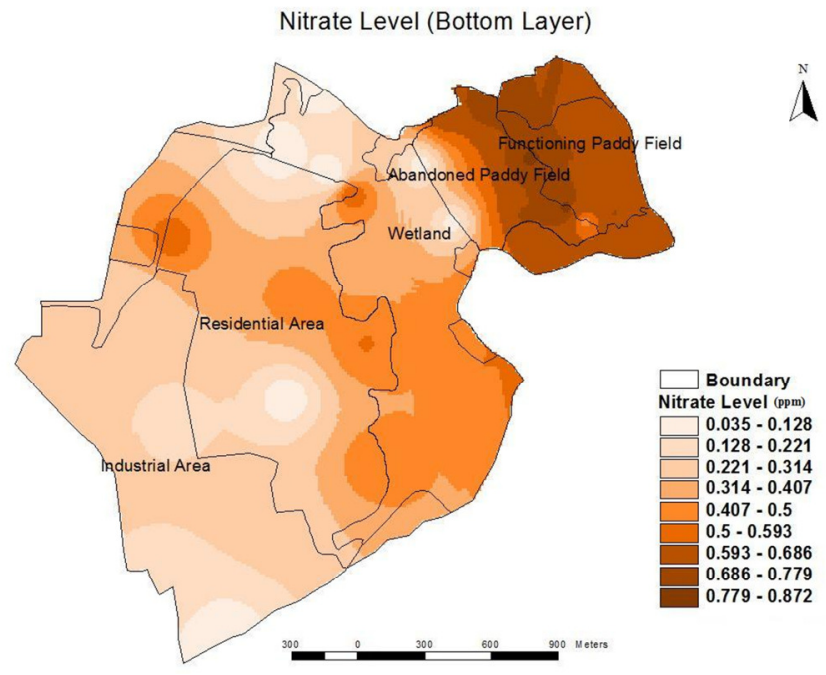

Figure 3: Distribution of water soluble nitrate in bottom soil layer in the study area 


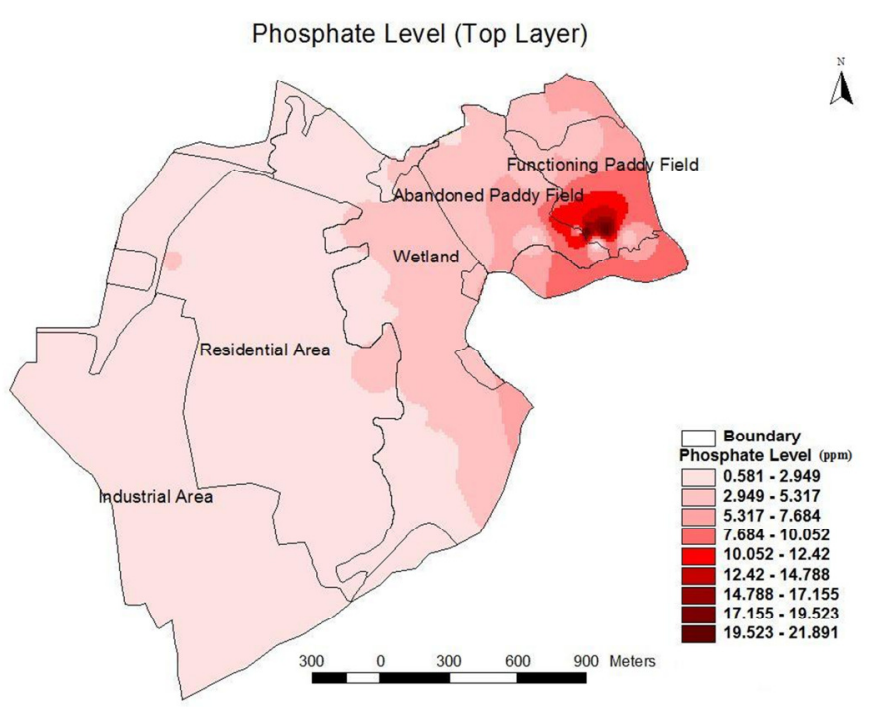

Figure 4: Distribution of water soluble phosphate in top soil layer in the study area

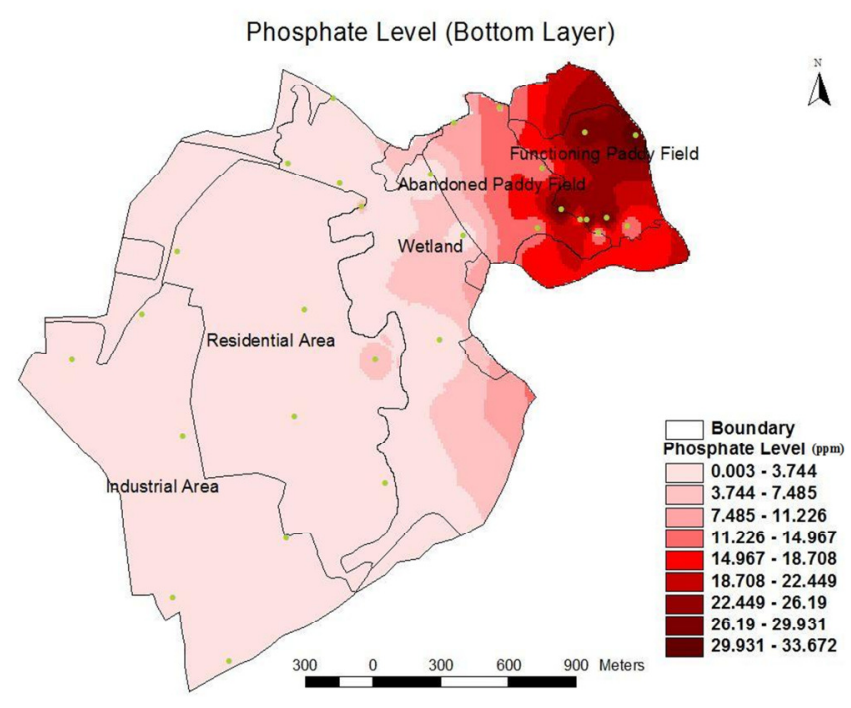

Figure 5: Distribution of water soluble phosphate in bottom soil layer in the study area

Salinity, electrical conductivity and chloride level showed a significant variability in top and bottom soils in different land use areas. The decline of salinity and electrical conductivity levels were recorded as;

Top: residential area $>$ industrial area $>$ wetland $>$ functioning paddy field $=$ abandoned paddy field Bottom: wetland $>$ residential area $>$ industrial area $>$ functioning paddy field $>$ abandoned paddy field

Chloride levels in the top soil layer showed a similar declining pattern except for the fact that chloride level in industrial area was overridden by the chloride level in residential area, while the bottom layer resembled exactly the same. Increased chloride, salinity and electrical conductivity level of the wetland and residential area (Figure 6,7 and 8), indicate saline intrusion.

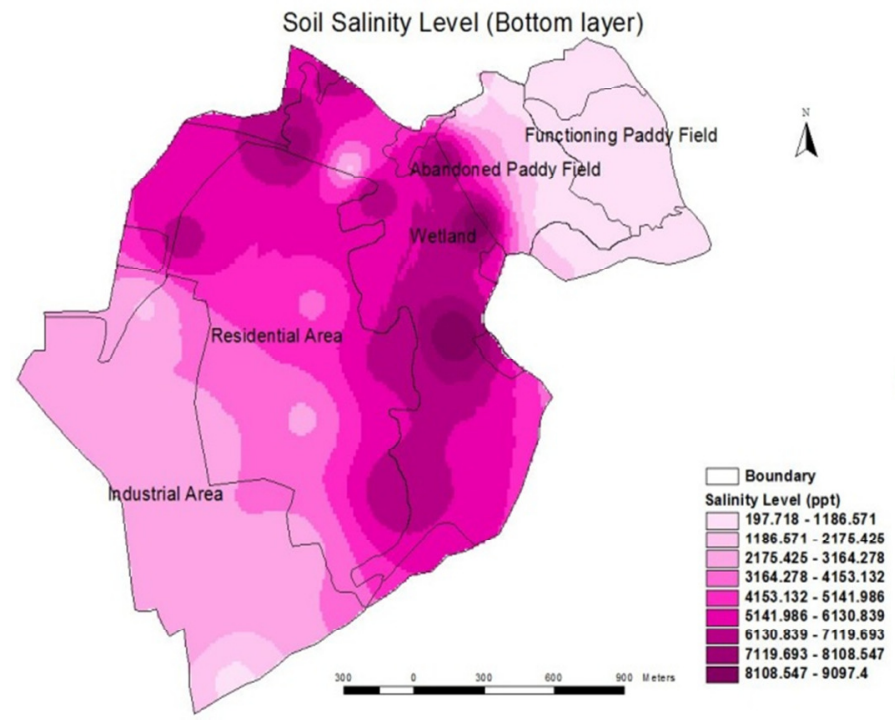

Figure 6: Distribution of salinity in bottom soil layer in the study area

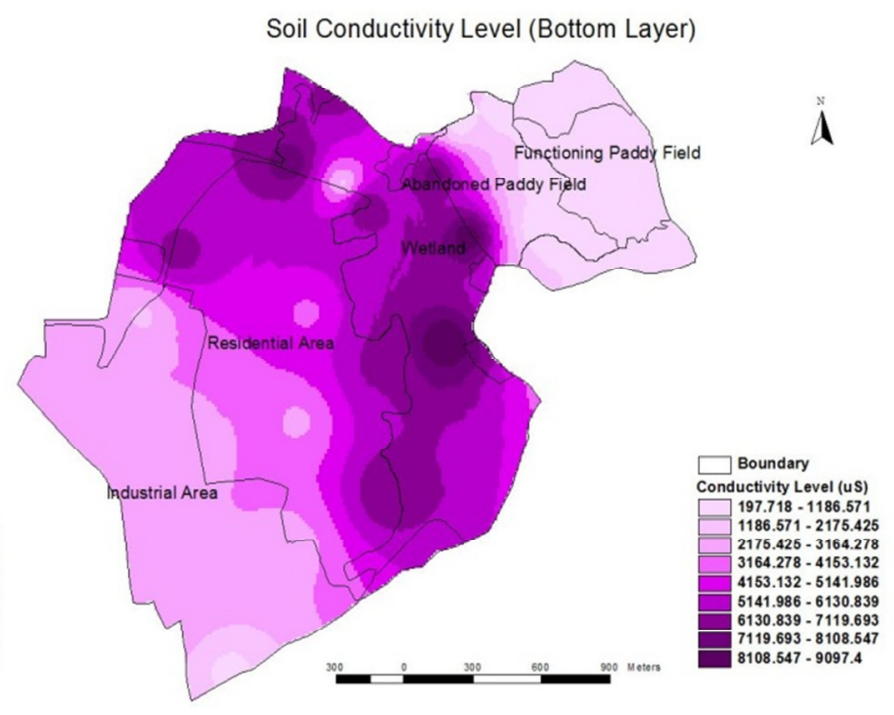

Figure 7: Distribution of electrical conductivity in bottom soil layer in the study area 


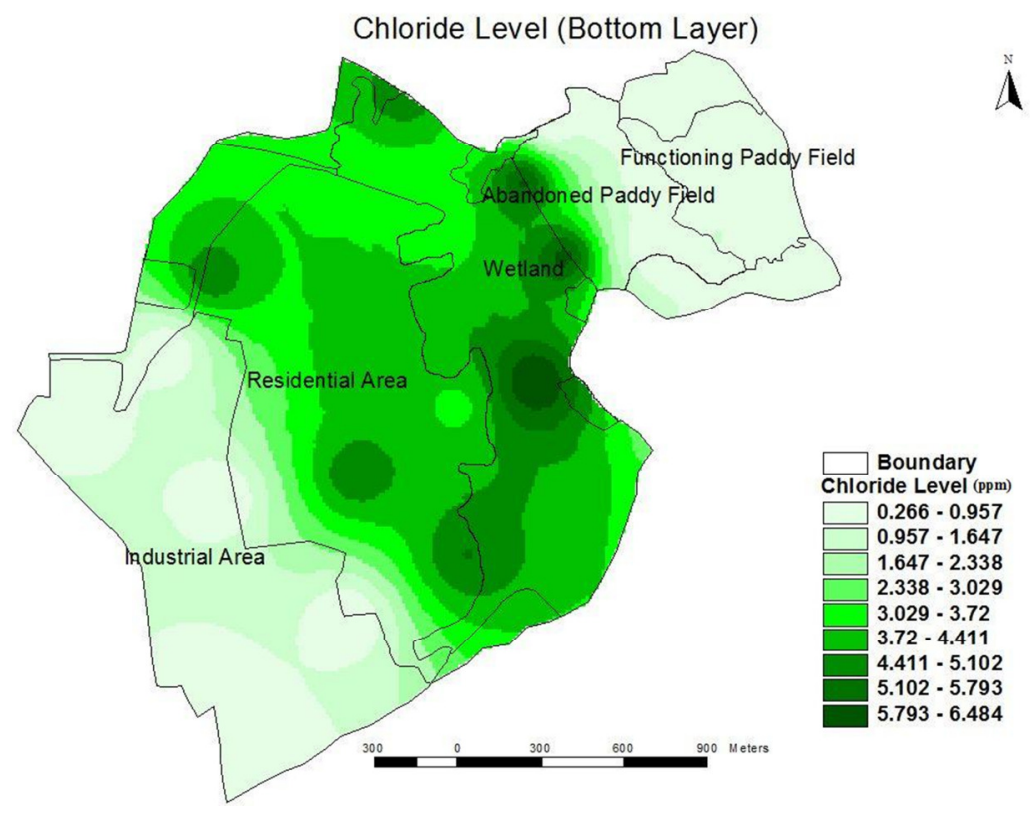

Figure 8: Distribution of water soluble chloride in bottom soil layer in the study area

\section{Discussion}

Bellanwila-Attidiya Wetland is the only natural landscape we came across in the study area and its soil resembled of typical wetland soil. It had high clay and moisture contents and lower pH (highly acidic) which is a characteristic property of hydric soils (Mitsch and Gosselink 1993, cited in Street, et al. 2005). Industrial area showed a significant difference in moisture content in both top and bottom soil layers from all the other land use areas, may be due to the high elevation levels recorded in the industrial area comparative to other land use areas.

A nitrate and phosphate contents were low in the wetland soil due to microbial reactions under anaerobic (Evens et al. 1996; Campbell et al., 2002) owing to water logged conditions (Omoregie and Akenova, 1999). Low level of nitrates and phosphates in top soils of functioning and abandoned paddy fields may be due to the same reason. Increase of nitrates and phosphates in bottom soil layer of functioning paddy field may be because of leaching (Chen et al. 2006) of nutrients supplemented by fertilizers (Glendininget al., 1996, Mukherjee et al., 2009). Elevated nitrate level was recorded in top soil layer in industrial area because absence of denitrification due to aerobic conditions of the soil which inhibits denitrification process and combustion of fossil fuels that produce $\mathrm{NO}_{\mathrm{x}}$ gasses which ultimately enriches soil by nitrates via precipitation (Miroslav and Vladimir, 1999).

Increased sulphate level in the wetland soil concurrent with literature had identified wetlands as sulphate sink (Richardson, 1995). Further wetland showed a significant difference in its bottom layer sulphate level from all the other land use areas while showing a significant difference with functioning paddy field, abandoned paddy field and residential area in top soil layer at 0.05 significant level.

Highest level of iron (III) was recorded in top soil of functioning paddy filed whilst residential area reported the highest level in bottom layer. The iron (III) levels in different land use areas arranged in descending order are as following; Top: functioning paddy field $>$ wetland $>$ residential area $>$ abandoned paddy field $>$ industrial area, Bottom: residential area $>$ functioning paddy field $>$ wetland $>$ abandoned paddy field $=$ industrial area.

The density of saline water is much higher than fresh water. Hence sea water intrusion generally occurs through bottom soil layers. Studies focused on Bolgoda Lake which is connected to the surface 
network of the Bellanwila-Attidiya wetland, reported elevated levels of salinity in the channel system (Piyadasa and Chandrasekara, 2010) which might have consequently contributed to the elevated salinity levels in soil. The lack of wetland studies reporting physical and chemical soil properties in the country makes it difficult to compare the levels that were found in this study. This study should be extended to include other important parameters including soil carbon contents and redox potentials. Nevertheless, these results could use as baseline data in wetland conservation planning.

\section{Conclusion}

While the soil properties of wetland resembles more of less "typical wetland soils", those in all other land use areas exhibit much variation indicating high human influences at least on the surface layers maps generated using GIS that have been developed clearly show the patterns of variation of soil properties.

Acknowledgements: Authors gratefully acknowledge the financial and logistical support provided by the University of Colombo.

\section{References}

Atapattu S.S., De Silva, S. and Sellamuttu, S.S., 2007. A Case for Integrated Water Resource Management in Sri Lanka. Wetlands and Agriculture International Irrigation Management Institute, Colombo, Sri Lanka.

Black, C.A.(eds.) 1965. Methods Of Soil Analysis, Part 1, Physical And Mineralogical Properties, Including Statistics Of Measurement And Sampling. American Society of Agronomy, Inc. p. 82-127, 331-344, 545-566.

Bruland, G. L. and Richardson, C.J. 2005. Spatial variability of soil properties in created, restored and paired natural wetlands. Soil Science Society of America Journal 69, 273-84

Campbell, D.A., C.A. Cole, and R.P. Brooks. 2002. A comparison of created and natural wetlands in Pennsylvania, USA. Wetlands Ecol. and Mgmt. 10, 41-49

Chen, X.M., Wu, H.S. and $\underline{\text { Sun, J.H. }}$. 2006. Time-spatial variability of ammonium and nitrate in farmland soil of Taihu Lake region, Abs. Huan Jing KeXue, 2006 Jun; 27(6), 1217-1222

Clesceri, L.S., Greenberg, A.E. and Eaton, A.D. 1999.Standard Methods for Examination of Water \& Wastewater, 20th Edition. Washington D.C: American Public Health Association, the American Water Works Association, and the Water Environment Federation

Cosmas M. 2009. Determination of the soil organic carbon, nitrogen, available phosphorus and the combined aboveground plant materials in the semi-arid Mbulu District, Tanzania. African Journal of Ecology, 47, 352-359

Cwikiel, Wilfred. 2003.Michigan wetlands - yours to protect: a citizen's guide to wetland protection. Third Edition.Tip of the Mitt Watershed Council, Petoskey, MI 49770

Evens, R., Gilliam, J. and Lilly, J. 1996.Wetlands and water quality. North Carolina Cooperative Extension Service, [online] Available from: www.bae.ncsu.edu/programs/extension/evans/ag4737.html [Accessed 8th November 2010].

Finlayson, C. M. 2007. Irrigation versus Ecosystems: What are the Choices?' Journal of the Australian Water Association. [online] Available from: http://ibcperu.nuxit.net/doc/isis/7578.pdf

Glendining, M. J.,Powlson, D. S.,Poulton, P. R., Bradbury, N. J., Palazzo, D. and Ll, X. 1996. The effects of long-term applications of inorganic nitrogen fertilizer on soil nitrogen in the Broadbalk Wheat Experiment, Abs. The Journal of Agricultural Science, 127, 347-363

Grunwald, S., Corstanje, R., Weinrich, B.E. and Reddy, K.R. 2006. Spatial patterns of labile forms of phosphorus in a subtropical wetland. Journal of Environmental Quality 35, 378-89 
Heidi, M. N. and Carolyn, E.O.,1997. Exchange dynamics of a shallow contaminated wetland boundaries. Volume, 193-213

Holland, M., Blood, E.R. and Shaffer, L.R. 2003. Achieving sustainable freshwater systems: a web of connections, Island Press

International Water Management Institute 2006.Sri Lanka wetlands information and database, Bellanwila-Attidiya sanctuary, [online], Available from:

http://dw.iwmi.org/wetland_profile/Bellanwila.asp [Accessed 6th November 2010]

Kidane, G. and Pieterse, J. 2006. Impact of grazing around a watering point on soil status of semi-arid rangelands in Ethiopia. Afr. J. Ecol. 45, 72-79

Kotagama, S.W. and Bambaradeniya, C.N.B 2006. An overview of the wetlands of Sri Lanka and their conservation significance. National Wetland Directory Of Sri Lanka, IUCN Sri Lanka and Central Environmental Authority, 7-16

Miroslav, R. and Vladimir, B.N. 1999.Practical Environmental Analysis. Cambridge, UK: Royal Society of Chemistry [online] Available from:

http://books.google.com.ec/books? $\mathrm{id}=\mathrm{o} 1 \mathrm{f} 4 \mathrm{hCVb1SgC \& printsec}=$ frontcover\&hl=en\#v=onepage \&q\& $\mathrm{f}=$ false, [Accessed 10 ${ }^{\text {th }}$ June 2011]

Mukherjee, A., Nair, V.D., Clark, M.W. and Reddy, K.R. 2009. Development of indices to predict phosphorus release from wetland soils, Journal of Environmental Quality, Volume 38, May-June 2009, 878-886.

Omoregie, A.U. and Akenova, M.E. 1999.P status and sorption capacities of some native rangeland soils in northern Nigeria. Tropical Agricultural Research and Extension, 2 (2), 101-106

Piyadasa, R. and Chandreasekara, K. 2010. Land use pattern and their impact on water quality in Bolgoda Lake basin- Sri Lanka, Abs. Geophysical Research Abstracts, Volume 12, EGU2010, 1195

Richardson, C.J. 1995. Wetland ecology. In Nierenberg, W.A. (eds) Encyclopaedia of Environmental Biology, Volume 3, Academic Press. Inc. 535-550

Street, M.W., Deaton, A.S.,Chapell, W.S. and Mooreside, P.D. 2005. North Carolina coastal habitat protection plan. North Carolina Department of Environment and Natural Resources, Division of Marine Fisheries, Morehead City, NC. 656

United States Environmental Protection Agency 1996. Environmental indicators of water quality in the United States. EPA 841-R-96-002. Office of Water (4503F). U.S. EnvironmentalProtection Agency, Washington, DC.

United States Environmental Protection Agency 2001. Values and Function of Wetlands. September 2001. Available from: http://www.epa.gov/owow/wetlands/pdf/fun_val.pdf [Accessed $3^{\text {rd }}$

November, 2011] 